EGU2020-4848, updated on 25 Jan 2021

https://doi.org/10.5194/egusphere-egu2020-4848

EGU General Assembly 2020

(c) Author(s) 2021. This work is distributed under

the Creative Commons Attribution 4.0 License.

\title{
What is the magma storage depth under Osorno Volcano (Southern Volcanic Zone, Chile)?
}

\author{
Tonin Bechon ${ }^{1}$, Jacqueline Vander Auwera ${ }^{1}$, Olivier Namur ${ }^{2}$, Paul Fugmann ${ }^{1}$, Olivier Bolle ${ }^{1}$, and \\ Luis Lara ${ }^{3}$ \\ ${ }^{1}$ Department of Geology, University of Liège, Belgium (tonin.bechon@uliege.be) \\ ${ }^{2}$ Department of Earth and Environmental Sciences, University of Leuven, Belgium \\ ${ }^{3}$ SERNAGEOMIN, Chile
}

The depth at which magma chamber processes take place below magmatic arcs and the parameters controlling them are highly debated. These questions are fundamental for our understanding of the global magma differentiation as well as the formation of the continental crust at convergent margins, but also for evaluating the risks associated with volcanic eruptions.

In the Central Southern Volcanic Zone (Central-SVZ) of the Chilean Andes, a thin continental crust (30-40 km) and the occurrence of a major fault zone (Linquiñe-Ofqui) likely favor rapid magma ascent. This segment of the arc is as a consequence one of the most active in Chile with several recent eruptions (e.g. Llaima 2009, Cordon Caulle 2011, Calbuco 2015, Villarrica 2015 \& 2019). The Central-SVZ is characterized by dominant mafic lavas (basalts, basaltic andesites), few rhyodacitic lavas, a noticeable compositional (Daly) gap in the intermediate compositions (andesites). Noteworthy, amphibole is usually absent, except in a few volcanoes (e.g. Calbuco) or only occurs as microliths in enclaves, which suggests rather low water contents. These observations contrast sharply with the Northern-SVZ where andesitic lavas are dominant and hydrous phases common.

We focused our research on the eruptive products of Osorno volcano $\left(41^{\circ} \mathrm{S}, \mathrm{CSVZ}\right)$ located between two volcanoes (Calbuco and Cordon Caulle) which recently showed very explosive eruptions and partly overlies an older Pleistocene eroded volcanic edifice (La Picada). A large series of samples were collected in four units spanning $200 \mathrm{kyr}$. They define a differentiation trend ranging from tholeiitic basalts to calk-alkaline dacites with a Daly Gap between 58 wt. \% and 63 wt. $\% \mathrm{SiO}_{2}$. Plagioclase and olivine are dominant before the gap while plagioclase and clino- and orthopyroxene dominate afterwards.

The use of recent thermobarometric models revealed two main storage regions: (1) at the $\mathrm{MOHO}$ interface (1-1.2GPa) and (2), at the upper/lower crust interface with rather low pressures (likely $\leq 0.3 \mathrm{Gpa}$ ). While at (1) primary magmas differentiate, (2) is interpreted as the depth of major differentiation and volatile exsolution. Thermodynamic simulations (Gualda et al., 2012; Ghiorso \& Gualda, 2015) support these (2) depth estimates and reproduce the main paragenesis by simple fractional crystallization at 0.1-0.2 GPa. Our results may explain the recent seismic unrest below Osorno (from 2015 to 2019) with earthquakes mostly taking place between 0.1-0.3 GPa (4-10km 
below the summit). We suggest that Osorno is an important target to perform a comprehensive petrological study aiming at characterizing the Central-SVZ magmatic arc and the magmatic storage depths. 